\title{
The metabolism of iron in piglets given labelled iron either orally or by injection
}

\author{
By R. BRAUDE, A. G. CHAMBERLAIN, M. KOTARBIŃSKA* \\ AND K. G. MITCHELL \\ National Institute for Research in Dairying, Shinfield, Reading
}

(Received 20 December 1961-Revised 8 March 1962)

It is recognized that piglets denied access to sources of iron other than sow's milk become anaemic, and in order to prevent the disease it is current practice to provide such pigs with supplementary Fe either orally or by injection. Seamer (1956) has comprehensively reviewed the literature on the subject and since the publication of this review many further reports have appeared. As judged by haemoglobin level and gain in weight, many of the methods described gave satisfactory results but provided no information on the quantitative requirement of the piglet for $\mathrm{Fe}$.

The daily $\mathrm{Fe}$ requirement of pigs has been assessed from a consideration of the rate of incorporation of the element into haemoglobin produced as the pig grows and, for example, a value of ro-I I mg/day (Kotarbińska, I $960 a, b$ ) has been calculated in this way. Venn, McCance \& Widdowson (I947) calculated that piglets must retain at least $7 \mathrm{mg} \mathrm{Fe} /$ day if they are to maintain the same proportion of $\mathrm{Fe}$ in their bodies as they had at birth. These figures differ considerably, mainly because the authors quoted found different values for growth rates and haemoglobin levels in their animals.

There is a considerable difference between the figures for daily requirement and daily allowance quoted in the literature, which can be attributed largely to the low and variable level of $\mathrm{Fe}$ absorption. Many factors are known to influence absorption; for example phosphates (Davidson, Fullerton, Howie, Croll, Orr \& Godden, I933) or calcium carbonate (Greig, 1960) reduce the percentage absorption, and reducing substances such as ascorbic acid may increase the uptake (Moore \& Dubach, 195I; Kotarbińska, $\mathrm{I} 960 a, b)$. Understandably, the size of the dose has a considerable influence upon percentage absorption. Thus Ullrey, Miller, Thompson, Ackermann, Schmidt, Hoeffer \& Luecke (1960) found that about $82,6 \mathrm{r}$ and $50 \%$ of the intake was apparently taken up from milk substitutes containing 25,35 and $125 \mathrm{mg} \mathrm{Fe} / \mathrm{kg}$ solids respectively. Matrone, Thomason \& Bunn (1960) have estimated that only $30 \%$ of the $\mathrm{Fe}$ from fortified cow's milk containing $60 \mathrm{mg} \mathrm{Fe} / \mathrm{kg}$ dry matter was utilized by pigs up to 60 days of age. They consider that $60 \mathrm{mg} \mathrm{Fe} / \mathrm{kg}$ dry matter of the diet is necessary for satisfactory weight gain and haemoglobin synthesis. The amount of $\mathrm{Fe}$ present in the body (cf. McCance \& Widdowson, 1937) and the oxidation state of the Fe (Moore, Arrowsmith, Welch \& Minnich, 1939) may also affect uptake.

The introduction of injectable iron-dextran compounds provided another method

* British Council Scholar from the Department of Animal Nutrition, Szkoła Główna Gospodarstwa Wiejskiego, Warsaw, Poland. 
for prevention and treatment of piglet anaemia. These compounds were originally developed for use in the treatment of hypochromic anaemia in man, and considerable information on their metabolism has accumulated; it is well summarized by Golberg (1958). Though such compounds have been given to piglets for several years, little specific information on the metabolism of the $\mathrm{Fe}$ of these compounds by the young pig is available. However, McDonald, Dunlop \& Bates (1955) have shown that some $93.5 \%$ of the $\mathrm{Fe}$ from a dose containing $\mathrm{I} 4 \mathrm{O} \mathrm{mg}$ appeared in the red cells of a piglet I4 days after injection. Also, several workers have reported the effects of administering these substances on formation of haemoglobin and on other blood constituents (cf. Conrad, Plumlee \& Beeson, 1958; Bauer \& Becker, 1959; Ullrey, Miller, West, Schmidt, Seerley, Hoeffer \& Luecke, I959).

This paper deals with a comparison of the retention, distribution and utilization for haemoglobin production of $\mathrm{Fe}$ provided either orally as a ferrous sulphate solution, or by injection as iron dextran, in an attempt to assess the suitability of these treatments in the prophylaxis of piglet anaemia. The results have also enabled an estimate to be made of the $\mathrm{Fe}$ requirements of the young pig.

\section{EXPERIMENTAL}

\section{Animals and management}

Litters of Large White pigs from the Institute's herd free from virus pneumonia were used for each of the five experiments. The piglets were allowed to suckle the sow normally until slaughter. The animals were housed indoors and had no access to sources of $\mathrm{Fe}$ other than sow's milk and creep food which was made available to those piglets that reached 3 weeks of age. All piglets were 3 days old at the beginning of each experiment.

In each of the five experiments, $\mathrm{Fe}$ was supplied either orally as labelled ferrous sulphate solution or by injection as labelled iron dextran.

In Expt I a litter of nine piglets was divided into three groups of three. The piglets in one group received a single dose of $30 \mathrm{mg}$ labelled $\mathrm{Fe}$ as $\mathrm{FeSO}_{4}$ by mouth. In the second group the piglets were given similarly $3 \circ \mathrm{mg}$ labelled $\mathrm{Fe}$ on each of the first 3 days of the experimental period, and in the third group the piglets received $30 \mathrm{mg}$ labelled $\mathrm{Fe}$ on each of the first 6 days of the period. It was intended to slaughter a piglet from each group I44, 240 and $384 \mathrm{~h}$ after the first dosing and to study the distribution of labelled $\mathrm{Fe}$ in the tissues of the animals so as to assess the influence of size of dose on absorption and haemoglobin synthesis. Unfortunately, for reasons unconnected with the treatment, two of the animals in group 2 had to be removed from experiment. The remaining animal in this group was killed $240 \mathrm{~h}$ after it had received its first dose.

In Expt 2 ten piglets were each given a single dose of $30 \mathrm{mg}$ labelled $\mathrm{Fe}$ as $\mathrm{FeSO}_{4}$ and were slaughtered at intervals over the following $48 \mathrm{~h}$.

In Expt 3 ten piglets from one litter were each injected with $3 \circ \mathrm{mg}$ labelled $\mathrm{Fe}$ as iron dextran. Again the animals were slaughtered at intervals after injection, this time over the following $96 \mathrm{~h}$, as it was expected that the rates of absorption of Fe would 
be slower and its movement between various organs and tissues would take longer than in piglets receiving the same dose of $\mathrm{Fe}$ by mouth.

In Expt 4 each of a litter of nine piglets was injected with a single dose of $180 \mathrm{mg}$ labelled $\mathrm{Fe}$ as iron dextran. This amount of $\mathrm{Fe}$ was the same as the largest dose given orally in Expt I, and was in the range (150-200 $\mathrm{mg}$ ) recommended for practical administration. The piglets were killed at intervals over the following $96 \mathrm{~h}$.

Finally, in Expt 5, the fate of labelled Fe from an injection of either $30 \mathrm{mg}$ or 180 $\mathrm{mg}$ of iron dextran was studied over an extended period. A litter of eight piglets was used, four of which received the low dose and four the high dose. One piglet from each group was killed $264,432,600$ or $768 \mathrm{~h}$ after injection. The period studied was extended to $768 \mathrm{~h}$, twice that in experiments involving oral dosing, as again it was expected that the rate of metabolism of Fe from iron dextran would be slower than that of $\mathrm{Fe}$ from the $\mathrm{FeSO}_{4}$ solution. The piglet given $30 \mathrm{mg}$ labelled $\mathrm{Fe}$ and killed at $264 \mathrm{~h}$ grew at an abnormally slow rate and the values concerning it have been omitted.

\section{Preparation of labelled ferrous sulphate and iron dextran}

${ }^{59} \mathrm{Fe}$, a $\gamma$-ray-emitting isotope of $\mathrm{Fe}$ with a half-life of $45 \cdot \mathrm{I}$ days, was prepared in a pile at the Atomic Energy Research Establishment, Harwell, by irradiating reduced $\mathrm{Fe}$ to a specific activity at zero time of approximately $\mathrm{I} \mathrm{mc} / \mathrm{g}$.

A weighed portion was placed in twice the stoichiometric amount of $3 \mathrm{~N}-\mathrm{HCl}$ in a flask fitted with a reflux condenser and gas inlet. Nitrogen was passed and the contents were boiled until all the Fe had gone into solution. The condenser was then removed and the contents were taken to dryness on a sand-bath. Water was added and, after further drying on the bath to remove excess $\mathrm{HCl}$, the residue was dissolved in water, and sulphur dioxide was bubbled through the solution for $20 \mathrm{~min}$ with gentle heating to reduce any $\mathrm{Fe}^{3+}$ to $\mathrm{Fe}^{2+}$. Once again $\mathrm{N}_{2}$ was passed and the solution boiled to remove excess $\mathrm{SO}_{2}$. A dilute solution of sodium hydroxide was cautiously added until a faint stable precipitate appeared which was then removed by the addition of one drop of $3 \mathrm{~N}-\mathrm{HCl}$. A quantity of sodium sulphate stoichiometric with that of $\mathrm{Fe}^{2+}$ was added and the solution was diluted so as to give a final concentration of $15 \mathrm{mg}$ $\mathrm{Fe} / \mathrm{ml}$. It contained for each mole of ferrous sulphate 2 moles of sodium chloride and a small additional amount of $\mathrm{SO}_{4}{ }^{2-}$ formed by the oxidation of $\mathrm{SO}_{2}$ when the ferric iron was reduced. Titration of this solution against standard potassium permanganate solution showed that $98 \%$ of the Fe was in the ferrous state.

The labelled iron dextran was kindly prepared by Benger Laboratories Ltd, from a solution of ferric chloride which was in turn prepared by the method of the British Pharmaceutical Codex (1958) from the same sample of radioactive reduced iron. The preparation contained $77.3 \mathrm{mg} \mathrm{Fe} / \mathrm{ml}$ as determined by radiochemical assay and $78 \cdot 0$ mg by a chemical method. It was similar in respect of absorption and utilization, as judged by tests on rabbits, to the commercially available iron dextran. 


\section{Methods of administration of labelled Fe}

Piglets given Fe orally received it as $2 \mathrm{ml}$ of the solution just described by a stomach tube (external diameter $\mathbf{2} \mathrm{mm}$, internal bore $\mathrm{I} \mathbf{m m}$ ) made of polyvinyl chloride. About I $\mathrm{ml}$ water was passed down the tube after the Fe solution to ensure that all the dose reached the stomach.

Animals allotted to receive 30 or $\mathrm{r} 80 \mathrm{mg} \mathrm{Fe}$ by injection received 0.39 or $2.33 \mathrm{ml}$ of the iron-dextran preparation respectively. The injection was deep into the right gluteal muscle. There was no loss of Fe from the site due to external leakage.

\section{Methods of taking samples}

After oral dosing. Blood samples were obtained either from the ear veins of pigs in Expt $\mathrm{I}$ at times shown in Table $\mathrm{I}$ or from the throats of other animals when they were slaughtered.

In each experiment the weights of piglets in the litters varied in the usual fashion. 'Heavier' and 'lighter' piglets were selected alternatively for slaughter at times shown in Tables I and 4. Immediately before killing, the piglets were weighed and were then stunned and bled. The animals were opened, organs taken out and all free blood was removed by swabbing. An estimate of the blood lost was made by reweighing the carcass and organs. Samples of various tissues were then taken for counting; one each was obtained from the fundic region of the stomach and from the colon, caecum and rectum walls; three were taken from the small intestine, one $15 \mathrm{~cm}$ from each end and one from the middle. The gut-wall samples were taken free from all connective and lymphatic tissue. They were then carefully washed in a stream of water and were blotted dry. Every effort was made to keep the mucosal surfaces intact as well as to remove all the gut contents from the samples. Samples were taken from the composite contents of the stomach, the ileum, the caecum, the colon and the rectum. The total weights of the tissues and of the gut samples were noted before sampling. The liver was removed, washed with saline, weighed and homogenized before three samples were taken for counting.

The remainder of the carcass (i.e. the carcass except blood removed, liver, stomach and intestines), designated as 'carcass' in the tables, was passed through a butcher's mincer several times, then a sample was taken and homogenized in a blender. Three subsamples of a size suitable for counting were taken from the homogenate. The specific activity of these three samples was always very close, the range never exceeding $2 \%$ of the mean.

After injection. Samples were taken as for the orally dosed animals, with the following exceptions.

At the conclusion of Expt 2 it appeared that there had been endogenous excretion of labelled $\mathrm{Fe}$. In an attempt to locate the route of excretion, in the event of a similar loss occurring also in piglets given iron dextran, samples of urine from the bladder and of bile from the gall-bladder were taken. Occasionally the bladders were empty and samples could not be obtained. 
The importance of the lymphatic system in the transport of iron dextran has been recognized for some time (Golberg, 1958) and, to establish how rapidly the level in the system decreased, in Expts 4 and 5 the right femoral lymph glands were removed from some animals which had received $\mathrm{I} 80 \mathrm{mg} \mathrm{Fe}$ as iron dextran.

Before the carcass was minced in the way described (p. 430) both hams were cut off and weighed. These hams were minced separately and sampled in the same way as the rest of the carcass. The difference between the concentrations of radioactive $\mathrm{Fe}$ in the hams enabled an estimate to be made of the amount of Fe remaining at the site of injection.

\section{Haemoglobin estimations}

In all experiments haemoglobin in blood was determined by the oxyhaemoglobin method.

A $0.05 \mathrm{ml}$ sample of blood was mixed with to $\mathrm{ml}$ of a $0.04 \%$ (v/v) aqueous solution of ammonium hydroxide. The mixture was allowed to stand for at least $\frac{1}{2} \mathrm{~h}$ and was then read in a Unicam photo-electric colorimeter which had been calibrated with blood of known haemoglobin content.

Haemoglobin in the blood remaining in the livers was estimated in Expts 2-5 by the method of Greenberg \& Erickson (1944) with the modification that the extinction of the ethereal solution of haemin was read in a Unicam photo-electric colorimeter against a standard curve constructed for the instrument with blood of known haemoglobin content. Values obtained in this way, used in conjunction with figures for the specific activity of whole blood and for the haemoglobin in blood at slaughter, provided a means of correcting the total activity of liver samples to give a true liver $\mathrm{Fe}$ value.

\section{Measurement of radioactivity}

Samples of known weight or volume were placed in flat-bottomed glass phials and the radioactivity was measured in a well-type thallium-activated sodium iodide scintillation counter. It had previously been found that the counting rate observed was independent of sample size up to $5 \mathrm{ml}$, and all samples taken for counting were therefore of a volume of $5 \mathrm{ml}$ or less. Counting rates were corrected to zero time by reference to a table (Wright, 1957) and for dead-time coincidence losses by reference to a curve previously constructed for the instrument. The counting efficiency was about $16 \%$, and the background about 300 counts $/ \mathrm{min}$.

\section{Calculation of amount of labelled Fe in circulation}

Figures for blood volume were taken from the literature (Hansard, Sauberlich \& Comar, I95 I; Aleksandrowicz, I955). A value of $75 \mathrm{ml} / \mathrm{kg}$ body-weight was adopted for all animals killed up to $264 \mathrm{~h}$ after dosing, and $70 \mathrm{ml} / \mathrm{kg}$ body-weight thereafter. These volumes were used together with the specific activities of whole blood to calculate the amounts of labelled Fe circulating in different pigs. 


\section{Blood fractionation}

Expt I. About o. $\mathrm{I} \mathrm{ml}$ blood was drawn periodically throughout the experiment into micro-haematocrit tubes from the ear veins of piglets given different amounts of labelled Fe. One end of the tube was sealed in a flame, the blood was allowed to clot and the tube was then centrifuged for $5 \mathrm{~min}$ at $500 \mathrm{~g}$. It was then marked with a diamond at the interface between serum and cells, broken at the mark, and the serum was blown into a weighed counting phial. After reweighing, the serum was diluted to $3 \mathrm{ml}$ and counted.

Results obtained in this way with blood drawn immediately before slaughter were compared with values for plasma obtained by centrifuging heparinized blood collected at slaughter. Agreement between the methods was good, showing the validity of the technique.

Expt 2. Heparinized blood $(20 \mathrm{ml})$, obtained at slaughter, was separated into plasma and cells by centrifugation in two $10 \mathrm{ml}$ graduated centrifuge tubes. The plasma was removed and a sample was counted after the approximate cell volume had been noted. The cells were washed with two $10 \mathrm{ml}$ portions of $0.85 \%(w / v) \mathrm{NaCl}$ solution, the washings were collected and a portion was counted. The cells were then haemolysed by the addition of about $6 \mathrm{ml}$ water to each tube and the cell debris was centrifuged down. The clear solution was removed and added to $80 \mathrm{ml}$ of a $0.1 \%(\mathrm{w} / \mathrm{v}) \mathrm{NaCl}$ solution in glacial acetic acid at $90^{\circ}$. The procedure of Fischer (194I) was used to obtain crude haemin, which was purified by the method of Shemin, London \& Rittenberg (1950). The crystals produced in this way were weighed and counted.

The contribution of labelled Fe from haemoglobin to the total activity of $\mathrm{I} \mathrm{ml}$ blood was calculated from the activity of haemin, values for the haemoglobin of the animal's blood at slaughter and the percentages of Fe in haemoglobin (0.34) and haemin $(8 \cdot 57)$. The contribution of the plasma to whole-blood activity was calculated by multiplying the specific activity of the plasma by the plasma volume.

Haemoglobin contaminating the cell debris was estimated by suspending the debris in a known volume of $0.04 \%(\mathrm{v} / \mathrm{v})$ ammonium hydroxide solution and measuring the extinction, after the debris had settled, under the same conditions as for blood haemoglobin. A suitable portion was then counted and the contribution of the haemoglobin present to the total activity of the debris was subtracted to give a measure of the activity of the cell walls.

Expts 3-5. In all treatments involving injection of iron dextran, $20 \mathrm{ml}$ heparinized blood collected at slaughter were centrifuged in graduated tubes and the plasma was removed after the approximate cell volume had been noted. A portion of the plasma was counted.

Of the plasma obtained from pigs in Expts 3 and $4,0.1 \mathrm{ml}$ was subjected to electrophoresis on Whatman $3 \mathrm{MM}$ paper in $0.02 \mathrm{M}$-veronal buffer at $\mathrm{pH} 8.6$ over a front of $10 \mathrm{~cm}$ at $560 \mathrm{~V}$ for $4 \mathrm{~h}$ to separate the iron dextran from the protein fractions. With some samples the iron-dextran content of the plasma was sufficiently high to enable the band to be seen. When the intensity of the colour was insufficient, $0.02 \mathrm{ml}$ of a 
$0.075 \%(\mathrm{v} / \mathrm{v})$ aqueous solution of unlabelled iron dextran was put on to the starting line with the plasma. After electrophoresis, the iron-dextran band was cut out and counted, and then the protein bands were developed by dipping the remainder of the strip in a $0.2 \%(\mathrm{w} / \mathrm{v})$ solution of ponceau-S in $3 \%(\mathrm{w} / \mathrm{v})$ trichloroacetic acid for Io min. After washing in $3 \%(\mathrm{w} / \mathrm{v})$ trichloroacetic acid, albumin, $\alpha$-globulin and $\beta$-globulin could be distinguished. The $\gamma$-globulin fraction could not be measured as it was partially obscured by the iron-dextran band. This was not considered to be important to this study, as it was thought that there was little possibility of Fe being associated with $\gamma$-globulins. The strip was cut into albumin, $\alpha$-globulin and $\beta$ globulin fractions and each segment was folded into a counting phial and counted. Also, plasma from all experiments was fractionated by the method of Bush, Mahoney, Mankowitz, Gubler, Cartwright \& Wintrobe (1955) to give a globulin precipitate, which should contain the Fe-binding transferrins, and a supernatant fraction containing albumin and iron dextran; each fraction was counted.

Two methods of fractionation of the plasma were used as neither was expected to be entirely satisfactory. Thus the separation of the iron-dextran and $\beta$-globulin bands was not sharp at high concentrations of iron dextran under the conditions used, and the precipitation of Fe-binding globulins from plasma by ammonium sulphate may not have been complete (Koechlin, 1952).

The cell fractions were washed twice with a total of $20 \mathrm{ml}$ of $0.85(\mathrm{w} / \mathrm{v}) \mathrm{NaCl}$ solution and then $12 \mathrm{ml}$ water were added to haemolyse the cells. No attempt was made to separate the cell debris from the solution of haemoglobin. The laked cells were then treated as in Expt 2 to yield a crystalline sample of haemin, which was counted. The proportions of whole blood activity that could be attributed to the haemin, iron dextran and $\beta$-globulin were calculated.

RESULTS AND DISCUSSION

'Retention'

Oral administration of Fe (Expts $\mathrm{I}$ and 2)

'Retention' is defined here as the difference between the total amount recovered at any one time from all fractions examined and the amount in the gut contents.

Values for absolute and percentage 'retention' of labelled Fe are presented for all piglets in Table I, together with their weights and haemoglobin levels at slaughter.

There was the usual variation in haemoglobin level in the blood. Only in one piglet which received $30 \mathrm{mg} F e$ and was killed $384 \mathrm{~h}$ after dosing was the blood haemoglobin level outside the range for normal pigs.

With the single dose of $30 \mathrm{mg}$ labelled $\mathrm{Fe}$, the total recovered after $2 \mathrm{~h}$ was calculated to be in excess of the amount administered. This discrepancy must be attributed to experimental error. Thereafter, up to $48 \mathrm{~h}$ after dosing there was a trend for the percentage recovery to decrease, probably owing to loss of considerable amounts of labelled $\mathrm{Fe}$ in the faeces. It should be noted that this trend continued up to $3^{84} \mathrm{~h}$, which is discussed on p. 437.

Absorption from the gut was rapid, being evident $2 \mathrm{~h}$ after administration. After 
$4 \mathrm{~h}$ about half of the largest quantity 'retained' had passed from the gut into the body. The absolute amounts 'retained' rose with the size of the dose. On the percentage basis, the dose of $90 \mathrm{mg}$ labelled Fe proved almost as efficient as the $30 \mathrm{mg}$ dose, since $240 \mathrm{~h}$ after dosing, piglet no. II, which had received three daily doses, contained 2.8 times the maximal amount found after administration of the single dose of $30 \mathrm{mg}$. However, piglets nos. 4 and io that received $180 \mathrm{mg}$ labelled Fe utilized the dose much less efficiently, the percentage 'retention' falling to about half that of the lower doses (about $3 \cdot 1$ times the amount from a dose six times as large), and even piglet no. 5 , which seemed to be exceptional in its efficiency, was able to 'retain' only $44 \%$ of its dose. It seems, therefore, that there is a decrease in the percentage of $\mathrm{Fe}$ 'retained' with increase in the total size of dose.

Table I. Expts I and 2. Recovery, and 'retention' by piglets, of labelled iron after oral dosing, expressed as absolute weights and as percentages of total amount administered

\begin{tabular}{|c|c|c|c|c|c|c|c|c|c|}
\hline \multirow{4}{*}{$\begin{array}{c}\text { Expt } \\
\text { no. }\end{array}$} & \multirow{4}{*}{$\begin{array}{l}\text { Time } \\
\text { after } \\
\text { first } \\
\text { dose } \\
\text { (h) }\end{array}$} & \multicolumn{4}{|c|}{ Piglet } & \multirow{2}{*}{\multicolumn{4}{|c|}{ Labelled Fe }} \\
\hline & & \multirow{4}{*}{ No. } & \multirow[b]{3}{*}{ Sex } & \multirow{4}{*}{$\begin{array}{l}\text { Weight } \\
\text { (lb) }\end{array}$} & \multirow{3}{*}{$\begin{array}{l}\text { Haemoglobin } \\
\text { at slaughter } \\
\text { (g/100 } \mathrm{ml} \\
\text { blood) }\end{array}$} & & & & \\
\hline & & & & & & \multicolumn{2}{|c|}{ Recovered } & \multicolumn{2}{|c|}{ 'Retained'* } \\
\hline & & & & & & $\mathrm{mg}$ & $\%$ & $\mathrm{mg}$ & $\%$ \\
\hline \multicolumn{8}{|c|}{ One dose of $30 \mathrm{mg}$} & & \\
\hline \multirow[t]{9}{*}{2} & 2 & 9 & q & 4.4 & 8.05 & $32 \cdot 0$ & $106 \cdot 7$ & $4 \cdot 2$ & 14.0 \\
\hline & 4 & 5 & 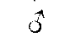 & $5 \cdot i$ & 8.05 & $25 \cdot I$ & $83 \cdot 7$ & $8 \cdot 9$ & $29 \cdot 7$ \\
\hline & 8 & $\mathbf{I}$ & $\hat{o}$ & $6 \cdot 0$ & $8 \cdot 40$ & $2 I \cdot I$ & $70 \cdot 4$ & $11 \cdot 8$ & $39 \cdot 3$ \\
\hline & 12 & 2 & q & $4 \cdot 1$ & $7 \cdot 88$ & $22 \cdot 6$ & $75 \cdot 3$ & $10 \cdot 2$ & 34.0 \\
\hline & 16 & 3 & $\hat{o}$ & 4.4 & $8 \cdot 40$ & $22 \cdot 0$ & $73 \cdot 3$ & 13.7 & $45 \cdot 7$ \\
\hline & 20 & 6 & $\hat{\sigma}$ & $5 \cdot 3$ & $8 \cdot 05$ & $21 \cdot 9$ & $73 \cdot 0$ & $15 \cdot 6$ & $52 \cdot 0$ \\
\hline & 24 & 8 & 우 & $4 \cdot 2$ & $9 \cdot 10$ & $27 \cdot 1$ & $90 \% 4$ & $14 \%$ & $48 \cdot 0$ \\
\hline & 36 & 7 & $\hat{0}$ & $5 \cdot 0$ & $7 \cdot 70$ & $16 \cdot 6$ & $55 \cdot 3$ & 15.5 & $5 x \cdot 7$ \\
\hline & 48 & 4 & q & $4^{*} 5$ & $6 \cdot 83$ & $20 \cdot 1$ & $67^{\circ} \circ$ & $18 \cdot 7$ & $62 \cdot 3$ \\
\hline \multirow[t]{3}{*}{ I } & 144 & 2 & $\hat{d}$ & $4 \cdot 8$ & $10 \cdot 15$ & 19.4 & 647 & $18 \cdot 6$ & $62 \cdot 0$ \\
\hline & 240 & 7 & + & $7 \cdot 6$ & $7 \cdot 35$ & $17 \cdot 3$ & $57 \cdot 7$ & $17 \cdot 2$ & $57 \cdot 3$ \\
\hline & $3^{84}$ & 3 & $\hat{o}$ & $10 \cdot 8$ & 475 & $12 \cdot 5$ & $41 \cdot 7$ & $12 \cdot 4$ & $4 I \cdot 3$ \\
\hline \multicolumn{10}{|c|}{ Three doses of $30 \mathrm{mg}$} \\
\hline $\mathbf{I}$ & 240 & I I & q & $6 \cdot 7$ & II'90 & $47 \cdot 9$ & $53 \cdot 3$ & $47 \cdot 6$ & $52 \cdot 9$ \\
\hline \multicolumn{10}{|c|}{ Six doses of $30 \mathrm{mg}$} \\
\hline \multirow[t]{3}{*}{ I } & I 44 & 4 & $\hat{0}$ & $4 \cdot 8$ & $8 \cdot 75$ & $62 \cdot 7$ & $34 \cdot 8$ & $56 \cdot 7$ & $3 I \cdot 5$ \\
\hline & 240 & I0 & $\hat{\sigma}$ & $8 \cdot I$ & 10.15 & $53 \cdot 5$ & $29 \cdot 7$ & $52 \cdot 9$ & $29 \cdot 4$ \\
\hline & 384 & 5 & 우 & $12 \cdot 8$ & $8 \cdot 75$ & $79 \cdot 3$ & $44^{\circ} \circ$ & $79 \cdot 1$ & $44 \cdot 0$ \\
\hline
\end{tabular}

Fig. I shows the concentrations of labelled $\mathrm{Fe}$ in the gut wall (including stomach wall) at different times after the single $30 \mathrm{mg}$ dose and also the mean concentration for all piglets in different segments of the gut wall. In agreement with the results of others (Heilmeyer, 1958; Brown \& Justus, 1958), we found the highest concentrations in the walls of the small intestine and the lowest in those of the large intestine (caecum, colon and rectum). Taking the gut as a whole, we found that the highest concentration was reached between 12 and $24 \mathrm{~h}$ after dosing, and that between 24 and $36 \mathrm{~h}$ it declined rapidly. It should be noted that the curve of concentration in the gut wall did not coincide with that for the concentration in blood (see Fig. 4), which shows 
that the findings for the gut could not have been affected by the presence of any residual amounts of blood (which was of relatively high activity) in the wall samples. If it is assumed that the $\mathrm{Fe}$ in the gut wall is largely in the form of ferritin, and that there is a limit to the concentration of this substance that can be reached in the gut tissues, it would seem that there would be more chance of $\mathrm{Fe}$ from succeeding doses being transferred to the intestinal walls if these doses were given after the fall in the concentration of $\mathrm{Fe}$ in the gut wall at $36 \mathrm{~h}$ had occurred. It is possible that this limit was reached, and that a 'mucosal block' of the type suggested by Hahn, Ball, Ross, Balfour \& Whipple (1943) was indeed set up in the piglets given three or more doses of $30 \mathrm{mg}$ labelled $\mathrm{Fe}$. This phenomenon would account for the very low percentage

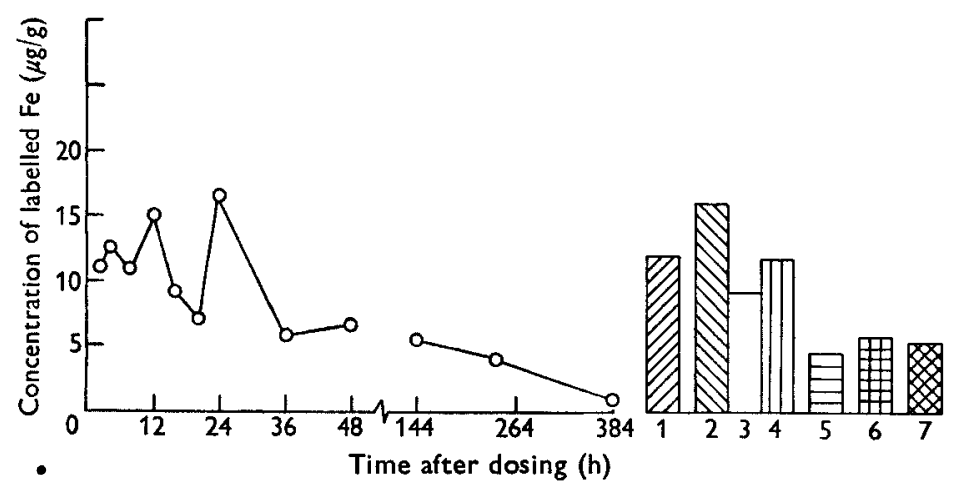

Fig. 1. Concentration of labelled iron in the gut wall of piglets at different times after a single $30 \mathrm{mg}$ dose, and mean concentrations in different segments of the gut wall. I, stomach; 2,3 and 4, stomach end, middle and caecum end, respectively, of the small intestine; 5, caecum; 6, colon; 7 , rectum.

Table 2. Expts I and 2. Labelled iron in gut contents of individual piglets at different times after dosing with $30 \mathrm{mg}$, calculated from the weight of gut contents and the concentration of labelled $\mathrm{Fe}$ in them

\begin{tabular}{|c|c|c|c|}
\hline $\begin{array}{l}\text { Time after } \\
\text { dosing } \\
\text { (h) }\end{array}$ & $\begin{array}{l}\text { Labelled Fe } \\
\text { in gut } \\
\text { contents } \\
\text { (mg) }\end{array}$ & $\begin{array}{l}\text { Time after } \\
\text { dosing } \\
\text { (h) }\end{array}$ & $\begin{array}{l}\text { Labelled Fe } \\
\text { in gut } \\
\text { contents } \\
\text { (mg) }\end{array}$ \\
\hline 2 & $27 \cdot 7$ & 24 & $12 \cdot 6$ \\
\hline 4 & $16 \cdot \mathrm{I}$ & 36 & $I \cdot I$ \\
\hline 8 & $9 \cdot 2$ & 48 & $1 \cdot 3$ \\
\hline 12 & $12 \cdot 3$ & I 44 & 0.8 \\
\hline 16 & $8 \cdot 4$ & 240 & 0.1 \\
\hline 20 & $6 \cdot 3$ & 384 & 0.1 \\
\hline
\end{tabular}

'retention' in the animals given a total of $180 \mathrm{mg}$ labelled Fe. Though current opinion (e.g. Moore, 196I) is opposed to the concept of the mucosal block, it seems to us that, with the physiologically large doses given, the mechanism may still hold, though the limited information available from our experiments does not permit definite conclusions to be drawn.

Table 2 shows the amounts of $\mathrm{Fe}$ remaining in the gut contents at different times 
after piglets had received a single dose of $30 \mathrm{mg}$ labelled Fe. Up to $24 \mathrm{~h}$ after dosing the amount remaining in the contents varied from 6.3 to $27.7 \mathrm{mg}$; subsequently it varied only from 0.1 to $\mathrm{I} \cdot 3 \mathrm{mg}$. This marked reduction was not accompanied by a corresponding rise in the amount of labelled $\mathrm{Fe}$ recovered from the tissues of the piglets (Table I), so it can be safely assumed that in the later period the piglets excreted considerable amounts of labelled $\mathrm{Fe}$ in the faeces. The fall in the amount of $\mathrm{Fe}$ in the gut walls also occurred during this period, suggesting that with the single oral dose of $30 \mathrm{mg}$ a close parallelism existed between the concentrations of Fe in the gut contents and gut walls.

Table 3. Expts I and 2. Distribution of labelled iron in tissues of piglets at different times after dosing, expressed as absolute weights and as a percentage of amount 'retained'

\begin{tabular}{|c|c|c|c|c|c|c|c|c|c|c|}
\hline \multirow[b]{3}{*}{$\begin{array}{c}\text { Expt } \\
\text { no. }\end{array}$} & \multirow[b]{3}{*}{$\begin{array}{c}\text { Piglet } \\
\text { no. }\end{array}$} & \multirow{3}{*}{$\begin{array}{l}\text { Time } \\
\text { after } \\
\text { first } \\
\text { dose } \\
\text { (h) }\end{array}$} & \multicolumn{8}{|c|}{ Labelled Fe content } \\
\hline & & & \multicolumn{2}{|c|}{ Liver } & \multicolumn{2}{|c|}{ Gut wall } & \multicolumn{2}{|c|}{ 'Other tissues' } & \multicolumn{2}{|c|}{ Blood } \\
\hline & & & $\mathrm{mg}$ & $\%$ & $\mathrm{mg}$ & $\%$ & $\mathrm{mg}$ & $\%$ & $\mathrm{mg}$ & $\%$ \\
\hline \multicolumn{11}{|c|}{ One dose of $30 \mathrm{mg}$} \\
\hline \multirow[t]{9}{*}{2} & 9 & 2 & 0.7 & 17 & $1 \cdot 3$ & $3 \mathbf{I}$ & $1 \cdot 7$ & 40 & 0.5 & 12 \\
\hline & 5 & 4 & $2 \cdot 5$ & 28 & $1 \cdot 7$ & 19 & $3 \cdot 8$ & 43 & 0.9 & Io \\
\hline & I & 8 & $3 \cdot 2$ & 27 & $2 \cdot 3$ & 20 & 4.7 & 40 & $x \cdot 6$ & 13 \\
\hline & 2 & 12 & $2 \cdot 9$ & 28 & $I \cdot 9$ & 19 & 4.0 & 39 & $\mathrm{r} \cdot 4$ & 14 \\
\hline & 3 & 16 & $4 \cdot 2$ & 31 & $I \cdot 2$ & 9 & $5 \cdot 6$ & 40 & $2 \cdot 7$ & 20 \\
\hline & 6 & 20 & 4.0 & 26 & $\mathrm{I} \cdot 2$ & 8 & $6 \cdot 8$ & 43 & $3 \cdot 6$ & 23 \\
\hline & 8 & 24 & $4 \cdot 3$ & 30 & $2 \cdot 4$ & I7 & $5 \cdot 4$ & 37 & $2 \cdot 3$ & I6 \\
\hline & 7 & 36 & $2 \cdot 9$ & 19 & $I \cdot 3$ & 8 & 5.7 & 37 & $5^{\cdot 6}$ & 36 \\
\hline & 4 & 48 & 2.7 & 14 & 0.9 & 5 & $5 \cdot 3$ & 28 & $9 \cdot 8$ & 53 \\
\hline \multirow[t]{3}{*}{ I } & 2 & 144 & $5 \cdot 7$ & 31 & 0.5 & 3 & $2 \cdot 2$ & I I & 10.2 & 55 \\
\hline & 7 & 240 & 0.7 & 4 & $I \cdot I$ & 6 & $4 \cdot 6$ & 27 & 10.8 & 63 \\
\hline & 3 & 384 & 0.7 & 5 & $O \cdot I$ & I & $1 \cdot 6$ & I3 & $10 \cdot 0$ & $8 I$ \\
\hline \multicolumn{11}{|c|}{ Three doses of $30 \mathrm{mg}$} \\
\hline I & I I & 240 & $3 \cdot 2$ & 7 & 0.9 & 2 & $\mathrm{I} \cdot 8$ & 4 & $4 r \cdot 7$ & 87 \\
\hline \multicolumn{11}{|c|}{ Six doses of $30 \mathrm{mg}$} \\
\hline \multirow[t]{3}{*}{ I } & 4 & 144 & $22 \cdot 1$ & 39 & $5 \cdot 7$ & 10 & $7 \cdot 9$ & I4 & $21 \cdot 0$ & 37 \\
\hline & 10 & 240 & $4 \cdot 2$ & 8 & $1 \cdot 6$ & 3 & $1 \cdot 8$ & 3 & $45 \cdot 3$ & 86 \\
\hline & 5 & 384 & $2 \cdot 6$ & 3 & $I \cdot I$ & I & $\mathbf{1} \cdot 4$ & 2 & $74^{\circ} \circ$ & 94 \\
\hline
\end{tabular}

* Total Fe recovered less that found in blood, liver, gut wall, stomach and gut contents.

As has been mentioned, Table I shows that the quantity of labelled Fe recovered from the tissues of animals given $30 \mathrm{mg} \mathrm{Fe}$ decreased in the period from 48 to $384 \mathrm{~h}$. This decrease can be explained by excretion of labelled Fe from the tissues of the piglets.

\section{Distribution}

Table 3 shows the total quantities of labelled $\mathrm{Fe}$ found in blood, liver, gut wall and other tissues at different time intervals after dosing with 30,90 and $180 \mathrm{mg} \mathrm{Fe}$, together with the percentage distribution of the 'retained' fraction from the $30 \mathrm{mg}$ dose in the sites examined. The quantity of $\mathrm{Fe}$ associated with blood, liver, gut wall 
and contents was subtracted from the total recovered, to give the quantities designated 'other tissues'.

The pattern of the distribution of Fe from a $30 \mathrm{mg}$ dose shows that in the course of the first $24 \mathrm{~h} \mathrm{Fe}$ moved from the gut wall mainly to the liver and other tissues, a smaller quantity being incorporated into the blood. Between 24 and $48 \mathrm{~h}$ the proportion in the liver and other tissues decreased rapidly, whereas that in the blood continued to mount steadily. In a third phase, after $48 \mathrm{~h}$, though there were more marked fluctuations in individual piglets, the proportions in sites other than the blood tended to decrease slowly. These findings are generally in agreement with those of Jensen, Bush, Ashenbrucker, Cartwright \& Wintrobe (1956).

The absolute values quoted in Table 3 confirm that in the period $24-48 \mathrm{~h}$ the uptake of labelled $\mathrm{Fe}$ by the blood from the liver was particularly intensive. After $48 \mathrm{~h}$ the total amount of labelled Fe circulating in the blood remained almost constant. Comparison of piglets nos. 7, I I and Io, all killed $240 \mathrm{~h}$ after the beginning of dosing but given respectively 30,90 and $180 \mathrm{mg}$ labelled $\mathrm{Fe}$, shows, as would be expected from the findings on 'retention', increasing amounts of labelled $\mathrm{Fe}$ in blood and liver with increase in dose. In the gut wall there was only a tendency for such an increase. It is noteworthy, however, that in 'other tissues' high amounts were found in the piglet with the lowest dose.

If all the piglets given one $30 \mathrm{mg}$ dose are considered (Table 3 ), the labelled Fe retained in the 'other tissues' remained at a relatively high level up to $240 \mathrm{~h}$. Though there was a marked fall between this time and $384 \mathrm{~h}$, there was no corresponding increase in any other site, which again suggests that this $\mathrm{Fe}$ was excreted. If it was indeed so, a possible explanation may be that as the dose was insufficient to prevent anaemia (Table I) the anaemia in turn affected erythropoietic processes which led to a less satisfactory utilization of Fe.

Though the number of piglets given the highest dose of $180 \mathrm{mg}$ was too small for assessment, findings with them indicate that at $\mathrm{I} 44 \mathrm{~h}$ they contained in 'other tissues' rather more $\mathrm{Fe}$ than piglets given $30 \mathrm{mg}$, and that the decline that occurred between 144 and $240 \mathrm{~h}$ was accompanied by an increase in the Fe content of the blood. These piglets were not anaemic.

The final distribution of 'retained' $\mathrm{Fe}$ at the last sampling after $3^{84} \mathrm{~h}$ indicates differences in the utilization of the administered $\mathrm{Fe}$ from a low dose, inadequate to prevent anaemia, and a higher one which enabled a satisfactory haemoglobin level to be maintained. In piglet no. 3 (haemoglobin $4.75 \%$ ), about $81 \%$ of the amount 'retained' was in the blood, about $5 \%$ in the liver, $\mathrm{I} \%$ in the gut wall and some $13 \%$ still in 'other tissues', whereas in piglet no. 5 (haemoglobin $8.75 \%$ ) $94 \%$ was in the blood, $3 \%$ in the liver, $1 \%$ in the gut wall and only $2 \%$ in 'other tissues'.

\section{Blood fractionation}

Expt I. Changes in the mean concentration of labelled $\mathrm{Fe}$ in serum and in the whole blood of piglets given 30,90 or $180 \mathrm{mg}$ Fe with time are shown in Figs. 2 and 3 respectively. 
In the serum of the piglets given $\mathrm{I} 80 \mathrm{mg}$ labelled $\mathrm{Fe}$ the maximum value reached was $9.05 \mu \mathrm{g} / \mathrm{ml} 96 \mathrm{~h}$ after the first dose. This concentration is within the range of the total Fe-binding capacity of plasma (Ullrey et al. 1960; Campbell, 196r). In general, the tendency was for piglets given greater numbers of doses to have higher serum $\mathrm{Fe}$ levels and to maintain them for longer periods than piglets given fewer doses. However, considerable variation in the serum levels of labelled $\mathrm{Fe}$ of individual piglets throughout the experimental period was found, making it difficult to establish close relationships between dose level, 'retention' of the element or the state of Fe depletion of the animals.

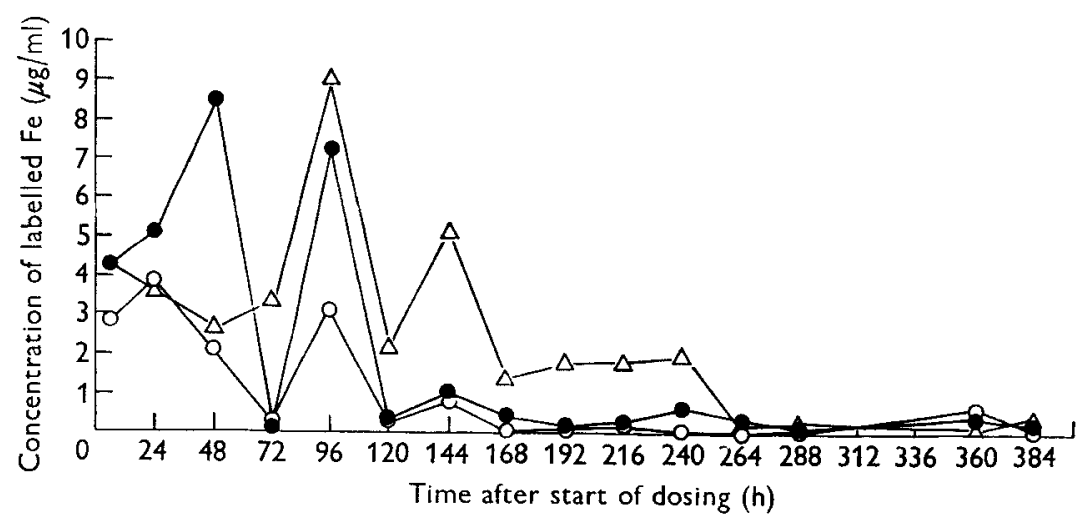

Fig. 2. Concentration of labelled iron in the blood serum of piglets given, $\bigcirc \longrightarrow$, $3 \circ \mathrm{mg}, \bullet-\bullet, 90 \mathrm{mg}$, or, $\triangle-\triangle$, i $80 \mathrm{mg}$ labelled Fe.

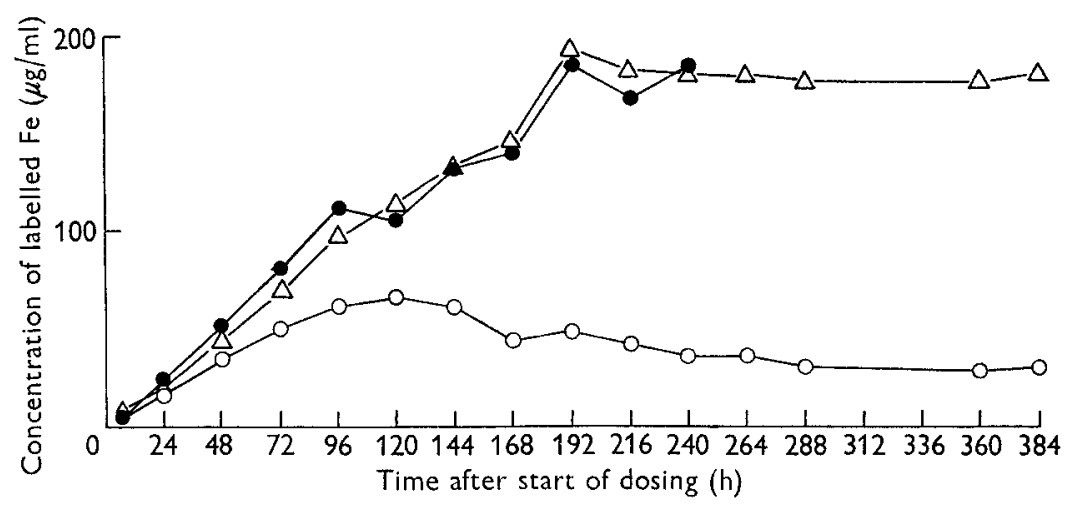

Fig. 3. Concentration of labelled iron in the whole blood of piglets given, $\longrightarrow \longrightarrow$, $30 \mathrm{mg}, \bullet-\bullet, 90 \mathrm{mg}$, or, $\Delta \longrightarrow \Delta, \mathrm{i} 80 \mathrm{mg}$ labelled Fe.

In the whole blood, the peak concentration for piglets given $30 \mathrm{mg}$ labelled $\mathrm{Fe}$ was reached $120 \mathrm{~h}$ after dosing, and in the piglets given either 90 or $180 \mathrm{mg}$ the peak concentration was reached about $192 \mathrm{~h}$ after the first dose. Though the concentration of labelled $\mathrm{Fe}$ in the blood of piglets must depend on the quantity in circulation and on the blood volume, the similarity between the two curves (Fig. 3) for the piglets given the higher doses again suggests that the final three doses of the $\mathrm{r} 80 \mathrm{mg}$ treatment were not well absorbed. 
The decrease in the concentration of $\mathrm{Fe}$ after $\mathrm{I} 2 \mathrm{O} \mathrm{h}$ in the piglets given $30 \mathrm{mg}$ can be explained by the diluting effect of the increase in blood volume of the piglets as they increased in size. In the piglets given the higher doses there was a sufficient reserve of Fe to offset this effect.

Expt 2. The weights of labelled $\mathrm{Fe}$ in $\mathrm{I} \mathrm{ml}$ whole blood and in the plasma and haemin isolated from it are shown in Fig. 4.

In the plasma, the maximum level of labelled Fe reached was $5.07 \mu \mathrm{g} / \mathrm{ml}$ in the piglet killed $8 \mathrm{~h}$ after dosing. This level is within the range of the total Fe-binding capacity of the plasma (Ullrey et al. 1960; Campbell, 196r). The level then fell until at $48 \mathrm{~h}$ there was only $0 \cdot 60 \mu \mathrm{g} / \mathrm{ml}$ plasma.

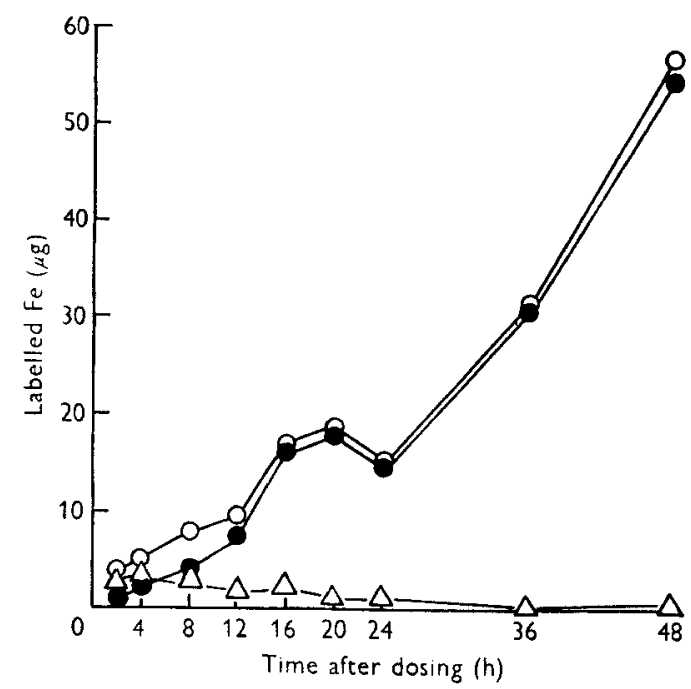

Fig. 4. Amount of labelled iron in, $0 \longrightarrow 0$, whole blood ( $\mathrm{I} \mathrm{ml}$ ) of piglets and in, $\bullet \bullet$, haemin and, $\Delta-\Delta$, plasma contained therein after a dose of $3 \circ \mathrm{mg}$.

There was a detectable amount of labelled Fe in the haemin isolated $2 \mathrm{~h}$ after dosing. The ability of circulating reticulocytes to incorporate $\mathrm{Fe}$ into haemoglobin probably accounts for this speedy appearance of labelled haemin in the blood stream (Jandl, Inman, Summons \& Allen, I959).

The concentration of labelled $\mathrm{Fe}$ in whole blood rose throughout, except for the piglet killed at $24 \mathrm{~h}$, and it will be seen from Fig. 4 that the sum of the contributions of haemin and of plasma adequately represented that of blood at all times. This finding was confirmed by the demonstration of absence of any activity in the cell debris; moreover, the activity of the cell washings was never in excess of that due to the small amount of plasma they contained. This result is at variance with that of Kotarbińska $(1960 a, b)$, who postulated that a further $\mathrm{Fe}$ fraction existed in whole blood of the type detected by Josephs (1954) and designated 'non-haemoglobin iron'. It is also of interest to note that Jensen et al. (I956) reported that $5 \mathrm{~h}$ after injection of ${ }^{59} \mathrm{FeCl}_{3}$ only $50 \%$ of the red-cell $\mathrm{Fe}$ was in haem, and that even after 5 days only $90 \%$ was incorporated into it; also that Jandl et al. (I959) were able to demonstrate that a proportion of the $\mathrm{Fe}$ taken up by reticulocytes from transferrins was associated with the cell walls. 
'Retention'

Injection of $\mathrm{Fe}$ (Expts 3-5)

'Retention' is defined here as the total amount of labelled Fe recovered, less that found in the stomach and gut contents, urine, bile and at the site of injection. Values for absolute and percentage 'retention' of labelled $\mathrm{Fe}$ are given for all piglets in Table 4, together with their weights and haemoglobin levels at slaughter.

Table 4. Expts 3, 4 and 5. Recovery, and 'retention' by piglets, of labelled iron after injection, expressed as absolute weights and as percentages of the total amount administered

\begin{tabular}{|c|c|c|c|c|c|c|c|c|c|}
\hline \multirow[b]{4}{*}{$\begin{array}{l}\text { Expt } \\
\text { no. }\end{array}$} & \multirow{4}{*}{$\begin{array}{l}\text { Time } \\
\text { after } \\
\text { in- } \\
\text { jection } \\
\text { (h) }\end{array}$} & \multicolumn{4}{|c|}{ Piglet } & & & & \\
\hline & & \multirow[b]{3}{*}{ No. } & \multirow[b]{3}{*}{ Sex } & \multirow[b]{3}{*}{$\begin{array}{l}\text { Weight } \\
\text { (lb) }\end{array}$} & \multirow{3}{*}{$\begin{array}{c}\text { Haemoglobin } \\
\text { at } \\
\text { slaughter } \\
\text { (g/loo ml } \\
\text { blood) }\end{array}$} & \multicolumn{4}{|c|}{ Labelled $\mathrm{Fe}$} \\
\hline & & & & & & \multicolumn{2}{|c|}{ Recovered } & \multicolumn{2}{|c|}{ 'Retained'* } \\
\hline & & & & & & $\mathrm{mg}$ & $\%$ & $\mathrm{mg}$ & $\%$ \\
\hline \multicolumn{10}{|c|}{ Injection of $30 \mathrm{mg}$ labelled $\mathrm{Fe}$} \\
\hline \multirow[t]{10}{*}{3} & 4 & 8 & o & $2 \cdot 2$ & $7 \cdot 53$ & $28 \cdot 2$ & $94^{\circ} \circ$ & $14 \cdot 1$ & $47 \cdot 0$ \\
\hline & I 2 & 9 & o & $3 \cdot 6$ & 7.88 & $29 \cdot 2$ & $97 \cdot 3$ & $24 \cdot 4$ & $81 \cdot 3$ \\
\hline & 24 & 7 & $\delta$ & 3.4 & 10.68 & $29 \cdot 6$ & $98 \cdot 7$ & $27 \cdot 3$ & $9 I \cdot 0$ \\
\hline & 36 & 4 & $\hat{\delta}$ & $5 \cdot 2$ & 9.10 & $3 I \cdot 0$ & $103 \cdot 3$ & $29 \cdot 7$ & $99 \cdot 0$ \\
\hline & 48 & 5 & $\sigma$ & 3.6 & $7 \cdot 18$ & $28 \cdot 5$ & $95^{\circ} \circ$ & $27 \cdot 7$ & $92 \cdot 3$ \\
\hline & 60 & I & 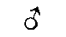 & $6 \cdot 1$ & $8 \cdot 93$ & $29 \cdot 3$ & $97 \cdot 7$ & $28 \cdot 2$ & $94^{\circ} \circ$ \\
\hline & 72 & 3 & q & $5 \cdot 2$ & $9 \cdot 10$ & $29 \cdot 9$ & $99 \cdot 7$ & $28 \cdot 3$ & $94 \cdot 3$ \\
\hline & 84 & 2 & 우 & $5 \cdot 4$ & $9 \cdot 28$ & $28 \cdot 8$ & 96.0 & $27 \cdot 4$ & $91 \cdot 3$ \\
\hline & 96 & IO & $\sigma^{x}$ & $6 \cdot 3$ & $8 \cdot 5^{8}$ & $29 \cdot 8$ & $99 \cdot 3$ & 27.9 & 93.0 \\
\hline & 108 & 6 & 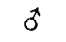 & 6.5 & $8 \cdot 75$ & $32 \cdot 5$ & $108 \cdot 3$ & $31 \cdot 7$ & 105.7 \\
\hline \multirow[t]{4}{*}{5} & $264 t$ & 2 & t & - & - & - & - & - & - \\
\hline & 432 & 8 & 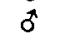 & $9 \cdot 6$ & $5 \cdot 60$ & $24 \cdot 9$ & $83 \cdot 0$ & $24 \cdot 6$ & $82 \cdot 0$ \\
\hline & 600 & 7 & $\sigma$ & 15.2 & $5 \cdot 25$ & $21 \cdot 7$ & $72 \cdot 3$ & $2 \mathrm{I} \cdot 2$ & 70.7 \\
\hline & 768 & 4 & 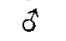 & $19 \cdot 6$ & $3 \cdot 85$ & 210 & $70 \cdot 0$ & 20.9 & $69 \cdot 7$ \\
\hline \multicolumn{10}{|c|}{ Injection of $180 \mathrm{mg}$ labelled $\mathrm{Fe}$} \\
\hline \multirow[t]{9}{*}{4} & 4 & 7 & 우 & $I \cdot 8$ & II 55 & $176 \cdot 5$ & $98 \cdot I$ & $59^{\circ} \mathrm{I}$ & $32 \cdot 4$ \\
\hline & 12 & I & 우 & $3 \cdot 3$ & $9 \cdot 45$ & $176 \cdot 3$ & $98 \cdot 0$ & $111 \cdot 0$ & $6 x \cdot 7$ \\
\hline & 24 & 9 & oै & $1 \cdot 3$ & $11 \cdot 38$ & $175 \cdot 9$ & $97 \cdot 7$ & $112 \cdot 0$ & $66 \cdot 4$ \\
\hline & 36 & $\mathbf{I}$ & 우 & $4 \cdot 5$ & 9.10 & 170.5 & $94 \cdot 7$ & $160 \cdot 1$ & $88 \cdot 8$ \\
\hline & 48 & 3 & q & $4 \cdot I$ & 9.80 & 165.0 & $91 \cdot 7$ & $16 I \cdot 2$ & $89 \cdot 4$ \\
\hline & 60 & 5 & $\sigma$ & 3.7 & 8.75 & $162 \cdot 2$ & $90 \cdot \mathrm{I}$ & $154^{\circ} \circ$ & $85 \cdot 7$ \\
\hline & 72 & 8 & 0 & $5 \cdot 3$ & 8.40 & $153^{\circ} 4$ & $85 \cdot 2$ & 145.2 & 80.5 \\
\hline & 84 & 4 & d & 5.0 & $10 \cdot 33$ & 155.9 & $86 \cdot 6$ & 140.8 & $78 \cdot 2$ \\
\hline & 108 & 6 & 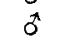 & 6.0 & IO. I 5 & 156.7 & 87.0 & $149^{\circ} 5$ & $83 \cdot 0$ \\
\hline \multirow[t]{4}{*}{5} & 264 & 6 & q & $6 \cdot 9$ & 9.80 & I $_{5} 8.8$ & $88 \cdot 2$ & I $55^{\circ} 9$ & $86 \cdot 7$ \\
\hline & 432 & 10 & 0 & 14.2 & 10.85 & I 75.5 & $97 \cdot 5$ & 173.8 & $96 \cdot 7$ \\
\hline & 600 & 9 & q & $17 \cdot 8$ & 10.15 & I $69^{\circ} 5$ & $94^{\cdot 2}$ & 168.6 & 93.7 \\
\hline & 768 & 3 & 우 & $24 \cdot 2$ & 8.75 & $I 7 I \cdot I$ & $95^{\cdot 2}$ & 170.1 & $94 \cdot 5$ \\
\hline
\end{tabular}

* Total Fe recovered less that found in gut contents, urine, bile and at the site of injection.

$\uparrow$ Piglet grew abnormally, values discarded.

Over a period of $264 \mathrm{~h}$ the mean amount of labelled Fe recovered from a $30 \mathrm{mg}$ injection remained remarkably constant and represented $99.3 \pm 4.3 \%$ of the dose. Thereafter, however, the amount declined and at the last measurement at $768 \mathrm{~h}$ was only some $70 \%$. Thus, the loss from the $30 \mathrm{mg}$ dose was similar to that after administration of the same quantity by mouth (p. 437) though it occurred at a later stage after 
administration. This analogy supports the conclusion from the experiments with oral administration that with a dose insufficient to prevent anaemia complete utilization of the Fe given does not take place, and that some of it is excreted. No such loss was observed after injection of $\mathrm{I} 80 \mathrm{mg}$ of labelled $\mathrm{Fe}$ and the mean amount recovered over the whole experimental period was $92 \cdot 7 \pm 4 \cdot 8 \%$.

Table 5. Expts 3, 4 and 5. Concentration of labelled iron in gut contents, urine and bile of piglets after injection

\begin{tabular}{|c|c|c|c|c|c|}
\hline \multirow[b]{2}{*}{$\begin{array}{c}\text { Expt } \\
\text { no. }\end{array}$} & \multirow[b]{2}{*}{$\begin{array}{c}\text { Piglet } \\
\text { no. }\end{array}$} & \multirow{2}{*}{$\begin{array}{c}\text { Time } \\
\text { after } \\
\text { injection } \\
\text { (h) }\end{array}$} & \multicolumn{3}{|c|}{ Labelled Fe content $(\mu \mathrm{g} / \mathrm{g})$} \\
\hline & & & $\begin{array}{c}\text { Gut } \\
\text { contents }\end{array}$ & Urine & Bile \\
\hline \multicolumn{6}{|c|}{ Injection of $30 \mathrm{mg}$ labelled $\mathrm{Fe}$} \\
\hline \multirow[t]{10}{*}{3} & 8 & 4 & 0.45 & 16.52 & $0.7 \mathrm{I}$ \\
\hline & 9 & 12 & 0.49 & $2 \cdot 36$ & 0.23 \\
\hline & 7 & 24 & 0.63 & $1 \cdot 05$ & * \\
\hline & 4 & 36 & 0.53 & 0.51 & * \\
\hline & 5 & 48 & 0.64 & 0.81 & * \\
\hline & $\mathbf{I}$ & 60 & 0.93 & 0.44 & 0.41 \\
\hline & 3 & 72 & 0.71 & 0.15 & $1 \cdot 03$ \\
\hline & 2 & 84 & 0.31 & 0.27 & 0.09 \\
\hline & 10 & 96 & 0.30 & 0.23 & 0.68 \\
\hline & 6 & IO8 & $0 \cdot 26$ & 0.20 & $x \cdot 69$ \\
\hline \multirow[t]{4}{*}{5} & 2 & $264 t$ & $\mathrm{I} \cdot 27$ & - & - \\
\hline & 8 & 432 & 0.39 & 0.06 & 0.29 \\
\hline & 7 & 600 & O.I I I & 0.01 & 0.01 \\
\hline & 4 & 768 & 0.12 & $*$ & 0.04 \\
\hline \multicolumn{6}{|c|}{ Injection of $\mathrm{x} 80 \mathrm{mg}$ labelled $\mathrm{Fe}$} \\
\hline \multirow[t]{9}{*}{4} & 7 & 4 & $8 \cdot 19$ & $80 \cdot 65$ & $28 \cdot 77$ \\
\hline & I & 12 & $2 \cdot 76$ & $44 \cdot 52$ & 3.94 \\
\hline & 9 & 24 & $29 \cdot 27$ & $70 \cdot 97$ & 69.03 \\
\hline & II & 36 & $3 \cdot 54$ & $*$ & 54.00 \\
\hline & 3 & 48 & $6 \cdot 05$ & II·55 & $1 \cdot 48$ \\
\hline & 5 & 60 & $7 \cdot 33$ & $17 \cdot 22$ & 0.52 \\
\hline & 8 & 72 & 3.02 & $*$ & $*$ \\
\hline & 4 & 84 & $2 \cdot 25$ & $1 \cdot 53$ & $*$ \\
\hline & 6 & I08 & I 46 & $2 \cdot 73$ & 0.35 \\
\hline \multirow[t]{4}{*}{5} & 6 & 264 & $4 \cdot 6 I$ & * & 0.62 \\
\hline & IO & 432 & $I \cdot 26$ & $0.3^{8}$ & 0.45 \\
\hline & 9 & 600 & 0.76 & 0.21 & 0.23 \\
\hline & 3 & 768 & 0.69 & 0.02 & 0.14 \\
\hline
\end{tabular}

At slaughter, samples of urine, bile and gut contents were analysed for labelled Fe. The results are presented in Table 5. As we were unable to measure the amounts of these materials, we do not know the proportions in which Fe was excreted by the three routes. We were able to establish, however, that, through all three, traces of $\mathrm{Fe}$ were travelling at all stages of the experiment. Further, the level of labelled $\mathrm{Fe}$ in the urine seems to have been related to the level of iron dextran in the plasma (see Figs. 7 and 8), there being appreciable falls in the plasma iron-dextran level and in that of labelled $\mathrm{Fe}$ of urine over the period from 4 to $3^{6} \mathrm{~h}$ after dosing in piglets given $3^{\circ} \mathrm{mg} \mathrm{Fe}$ as iron 
dextran, and over the period from 4 to $84 \mathrm{~h}$ when they were given $\mathrm{I} 80 \mathrm{mg}$. It may also be seen that the three highest values for labelled $\mathrm{Fe}$ in the bile occurred when the level of circulating iron dextran was high in the piglets given $180 \mathrm{mg} \mathrm{Fe}$, and that the level in the gut contents was considerably higher after the injection of 180 than of $30 \mathrm{mg} \mathrm{Fe}$.

It will be seen from Table 6 that $\mathrm{Fe}$ was rapidly removed from the site of injection. Already $36 \mathrm{~h}$ after the $30 \mathrm{mg}$ dose and $48 \mathrm{~h}$ after the $\mathrm{i} 80 \mathrm{mg}$ dose some $97 \%$ of the $\mathrm{Fe}$ was recovered away from the site.

Table 6. Expts 3, 4 and 5. Distribution of labelled iron in tissues of piglets at different times after injection, expressed as absolute weights and as a percentage of amount recovered

\begin{tabular}{|c|c|c|c|c|c|c|c|c|c|c|c|c|}
\hline \multirow{3}{*}{$\begin{array}{c}\text { Expt } \\
\text { no. }\end{array}$} & \multirow{3}{*}{$\begin{array}{c}\text { Piglet } \\
\text { no. }\end{array}$} & \multirow{3}{*}{$\begin{array}{c}\text { Time } \\
\text { after } \\
\text { injection } \\
\text { (h) }\end{array}$} & \multicolumn{10}{|c|}{ Labelled Fe content } \\
\hline & & & \multicolumn{2}{|c|}{ Blood } & \multicolumn{2}{|c|}{ Liver } & \multicolumn{2}{|c|}{ Gut wall } & \multicolumn{2}{|c|}{$\begin{array}{l}\text { 'Other } \\
\text { tissues'* }\end{array}$} & \multicolumn{2}{|c|}{ Site } \\
\hline & & & mg & $\%$ & $\mathrm{mg}$ & $\%$ & mg & $\%$ & $\mathrm{mg}$ & $\%$ & mg & $\%$ \\
\hline \multicolumn{13}{|c|}{ Injection of $30 \mathrm{mg}$ labelled $\mathrm{Fe}$} \\
\hline \multirow[t]{10}{*}{3} & 8 & 4 & 6.7 & 24 & 0.7 & 2 & 0.4 & $\mathbf{I}$ & $6 \cdot 3$ & 22 & $14 \cdot 1$ & $5 \mathrm{I}$ \\
\hline & 9 & 12 & $7 \cdot 9$ & 27 & $2 \cdot 6$ & 9 & $I \cdot \mathbf{I}$ & 4 & $12 \cdot 8$ & 44 & $4 \cdot 8$ & r6 \\
\hline & 7 & 24 & $3 \cdot 2$ & I I & $6 \cdot 2$ & 21 & 0.9 & 3 & $17 \cdot 0$ & $5^{8}$ & $2 \cdot 2$ & 7 \\
\hline & 4 & 36 & 3.9 & 12 & $5 \cdot 0$ & 16 & 0.9 & 3 & I9.9 & 65 & $1 \cdot 2$ & 4 \\
\hline & 5 & 48 & 3.6 & 12 & $3 \cdot 9$ & 14 & 0.8 & 3 & $19 \cdot 6$ & 68 & 0.8 & 3 \\
\hline & I & 60 & $7 \cdot 6$ & 26 & $2 \cdot 7$ & 9 & $I \cdot 0$ & 3 & 16.9 & $5^{8}$ & $I \cdot I$ & 4 \\
\hline & 3 & 72 & $8 \cdot 3$ & 28 & $3 \cdot 4$ & II & 0.8 & 3 & 15.8 & 53 & $1 \cdot 5$ & 5 \\
\hline & 2 & 84 & $8 \cdot 4$ & 29 & $2 \cdot 9$ & 10 & 0.9 & 3 & I 5.2 & 53 & I. 4 & 5 \\
\hline & 10 & 96 & $13 \cdot 3$ & 45 & $I \cdot 7$ & 6 & 0.6 & 2 & I $2 \cdot 3$ & $4 I$ & I. 9 & 6 \\
\hline & 6 & 108 & 14.7 & 45 & $x \cdot 2$ & 4 & 0.5 & I & 15.3 & 47 & 0.8 & 3 \\
\hline \multirow[t]{4}{*}{5} & 2 & $264 t$ & - & - & - & - & - & - & - & - & - & - \\
\hline & 8 & 432 & 19.9 & 80 & 0.8 & 3 & 0.4 & 2 & 3.5 & 14 & 0.2 & $\mathbf{I}$ \\
\hline & 7 & 600 & $15 \cdot 2$ & 70 & 0.3 & $\mathbf{I}$ & 0.1 & $\mathbf{I}$ & $5 \cdot 6$ & 25 & 0.4 & 3 \\
\hline & 4 & 768 & $20 \cdot 0$ & 95 & 0.5 & 2 & 0.2 & I & 0.2 & $\mathbf{I}$ & $0 \cdot \mathbf{I}$ & $\mathbf{I}$ \\
\hline \multicolumn{13}{|c|}{ Injection of $180 \mathrm{mg}$ labelled $\mathrm{Fe}$} \\
\hline \multirow[t]{9}{*}{4} & 7 & 4 & $30 \cdot 3$ & 17 & $2 \cdot 2$ & $\mathbf{I}$ & $\mathrm{I} \cdot 8$ & $\mathbf{I}$ & $24 \cdot 8$ & 14 & $\operatorname{Ir} 7 \cdot 1$ & 67 \\
\hline & $\mathbf{I}$ & 12 & $43 \cdot 7$ & 25 & $7 \cdot 0$ & 4 & $3 \cdot 0$ & 2 & $57 \cdot 3$ & 33 & $65 \cdot I$ & 36 \\
\hline & 9 & 24 & $32 \cdot 3$ & I8 & $12 \cdot 8$ & 7 & 3.7 & 2 & $63 \cdot 2$ & 36 & $63 \cdot 4$ & 36 \\
\hline & I I & 36 & $38 \cdot 6$ & 23 & $22 \cdot 2$ & 13 & 5.0 & 3 & $94 \cdot 3$ & 56 & IO. I & 5 \\
\hline & 3 & $4^{8}$ & $27 \cdot 5$ & 17 & 30.5 & I 8 & $5 \cdot 8$ & 4 & $97 \cdot 4$ & 59 & $3 \cdot 3$ & 2 \\
\hline & 5 & 60 & 24.7 & I 5 & $29^{\circ} \mathrm{I}$ & I8 & $3 \cdot 6$ & 2 & $96 \cdot 6$ & 60 & $7 \cdot 3$ & 5 \\
\hline & 8 & 72 & 10.2 & 7 & $47 \cdot 4$ & 31 & $4 \cdot 4$ & 3 & $83 \cdot 2$ & 54 & $7 \cdot 9$ & 5 \\
\hline & 4 & 84 & 9.7 & 6 & $44 \cdot 2$ & 28 & $5^{\cdot 2}$ & 3 & $8 \mathrm{r} \cdot 7$ & 53 & 14.7 & 10 \\
\hline & 6 & 108 & 20.9 & I3 & $3^{8} \cdot 1$ & 24 & $4 \cdot 4$ & 3 & $86 \cdot I$ & 55 & $7 \cdot 0$ & 5 \\
\hline \multirow[t]{4}{*}{5} & 6 & 264 & $47 \cdot 4$ & 30 & $28 \cdot 2$ & I8 & $3 \cdot 6$ & 2 & $76 \cdot 7$ & 49 & $2 \cdot 3$ & I \\
\hline & IO & 432 & $106 \cdot 9$ & $6 I$ & $10 \cdot 3$ & 6 & 4.5 & 2 & $52 \cdot 1$ & 30 & $I \cdot 2$ & I \\
\hline & 9 & 600 & I I $4^{\circ} \circ$ & 67 & $5 \cdot 5$ & 3 & $2 \cdot 1$ & I & $47^{\circ} \circ$ & 28 & 0.8 & I \\
\hline & 3 & 768 & $148 \cdot 3$ & 87 & $2 \cdot I$ & I & $1 \cdot 9$ & I & $17 \cdot 8$ & Io & 0.7 & $\mathbf{I}$ \\
\hline
\end{tabular}

* Total Fe recovered less that found in blood, liver, gut wall and contents, urine, bile and the site of injection.

$\uparrow$ Piglet grew abnormally, values discarded.

\section{Distribution}

The absolute amounts and the percentage distribution of labelled $\mathrm{Fe}$ found in the blood, liver, gut wall, site of injection and in 'other tissues' at different times are given in Table 6. Here 'other tissues' does not include Fe found at the site of injection. 
The measurements showed that the Fe removed from the site of injection was transported by the blood to the liver and 'other tissues'. Though we did not analyse the lymph, its brown colour shortly after the injection showed that it was also taking part in transport, which agrees with the findings of Golberg (1958). The percentage of labelled $\mathrm{Fe}$ in blood (Table 6) showed a peak within $\mathrm{I} 2 \mathrm{~h}$ of injection with both doses and a trough between 24 and $48 \mathrm{~h}$ with the $30 \mathrm{mg}$ dose and between 72 and $84 \mathrm{~h}$ with the $180 \mathrm{mg}$ dose, and thereafter with both a steady rise. The liver peaks occurred at the times of the blood troughs and the subsequent steady decline in the liver curves

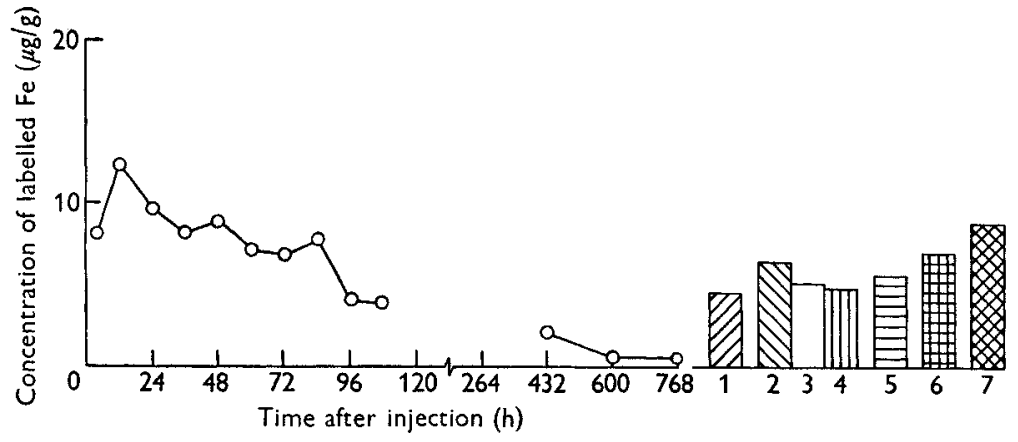

Fig. 5. Concentration of labelled iron in the gut wall of piglets at different times after a $30 \mathrm{mg}$ injection, and mean concentrations in different segments of the gut wall. I, stomach; 2,3 and 4, stomach end, middle end and caecum end, respectively, of the small intestine; 5 , caecum; 6 , colon; 7 , rectum.

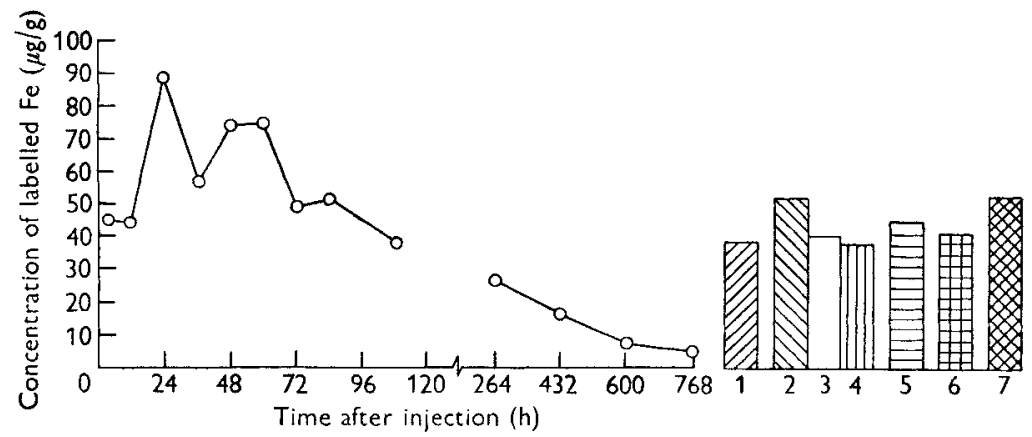

Fig. 6. Concentration of labelled iron in the gut wall of piglets at different times after a $180 \mathrm{mg}$ injection, and mean concentrations in different segments of the gut wall. $\mathbf{I}$, stomach; 2, 3 and 4, stomach end, middle and caecum end, respectively, of the small intestine; 5 , caecum; 6 , colon; 7 , rectum.

coincided with the steady rise of the blood curves. These findings can be explained by Golberg's (1958) view that the iron-dextran complex is broken down in the liver before it is used for formation of haemoglobin. As will be shown on pp. 445,446 we detected little iron dextran in the blood later than $36 \mathrm{~h}$ after the small dose and $7^{2} \mathrm{~h}$ after the large one, which again agrees with the concept of the breakdown of the complex in the liver.

With the large dose, the highest amount of Fe found in a liver was $47.4 \mathrm{mg}$. This value is much higher than any attained after oral dosing. For example, Ullrey et al. 
( 1960 ) found $8 \mathrm{mg}$ in the liver of piglets given large daily doses of $\mathrm{Fe}$, Kotarbińska ( $1960 \mathrm{a}$ ) found $10-13 \mathrm{mg}$, and in our own piglets given orally $180 \mathrm{mg}$ the highest amount of labelled Fe recorded was $22 \mathrm{mg}$ (see Table 3 ). The results of Muir \& Golberg (I96I) suggest that this Fe was initially in the form of iron dextran, but that continuous transformation to the storage proteins ferritin and haemosiderin was probably taking place.

The concentration of labelled $\mathrm{Fe}$ in the intestines at different times after the injection of 30 and $180 \mathrm{mg}$ and the mean concentration in different sections are shown in Figs. 5 and 6 respectively, these values having been calculated from values obtained in Expts 3-5. As with the oral dose of $30 \mathrm{mg}$, the concentrations of labelled $\mathrm{Fe}$ in the gut walls did not parallel changes in labelled Fe of the blood, from which we conclude that the gut wall activity was not due to the presence of blood. Gut wall activity may be due to the presence of small quantities of ferritin, or to iron dextran associated with the lymphatic system which is so widely distributed throughout the gut wall.

As shown in Table 6, a large part of the Fe recovered from the body was in the 'other tissues' which with both doses contained, between 24 and $3^{6} \mathrm{~h}$ after injection, about $60 \%$ of the total. This storage persisted for a long time and in the period $3^{6-}$ $264 \mathrm{~h}$ declined only to $50 \%$. Thereafter, however, the fall in absolute terms was marked, and with the large dose was accompanied by a further rise in the amount of $\mathrm{Fe}$ in the blood. This rise was not noted with the small dose, and it seems evident that, as with the smallest oral dose, the Fe leaving 'other tissues' must have been excreted, though rather later. We see no clear explanation of the persistence of such a large proportion of the labelled $\mathrm{Fe}$ in 'other tissues'. It may be that it was locked there in the lymphatic glands from which it was released only with difficulty. As an illustration of the storage of labelled Fe in the lymphatic tissues, we give below the concentrations found in the right femoral lymph gland at various times after injection of the large dose.

$\begin{array}{cc}\begin{array}{c}\text { Time after } \\ \text { injection } \\ (\mathrm{h})\end{array} & \begin{array}{c}\text { Labelled Fe } \\ \text { in gland } \\ (\mu \mathrm{g} / \mathrm{g})\end{array} \\ 72 & 1730 \\ 246 & 7070 \\ 432 & 550 \\ 600 & 360 \\ 768 & 310\end{array}$

On the other hand, the $\mathrm{Fe}$ in 'other tissues' may represent a true store to be called upon when the liver store becomes depleted.

At the end of the experiments with the $30 \mathrm{mg}$ dose, $768 \mathrm{~h}$ after injection, of the total amount of labelled $\mathrm{Fe}$ in the body, $95 \%$ was in the blood, about $2 \%$ in the liver and about $\mathrm{I} \%$ in each of the gut wall, site of injection and 'other tissues'. With the large dose the distribution was $87 \%$ in the blood, $\mathrm{x} \%$ in each of the liver, gut wall and the site of injection, but the 'other tissues' still contained $10 \%$. This last finding suggests that with the $180 \mathrm{mg}$ dose the process of utilization of the injected $\mathrm{Fe}$ was not yet completed. 


\section{Blood fractionation}

Expt 3. The amounts of labelled $\mathrm{Fe}$ in $\mathrm{I} \mathrm{ml}$ of whole blood from piglets injected with $30 \mathrm{mg}$ labelled $\mathrm{Fe}$ and in fractions prepared from it are shown in Fig. 7. As only negligible activity was detected in the $\alpha$-globulin and albumin fractions, values for them are omitted.

The amounts of labelled Fe associated with dextran and $\beta$-globulin fractions prepared by electrophoresis agreed well with those associated with the supernatant liquid and globulin precipitate respectively as prepared by $\left(\mathrm{NH}_{4}\right)_{2} \mathrm{SO}_{4}$ precipitation. As expected, the level of labelled iron dextran in the plasma was very high initially, and

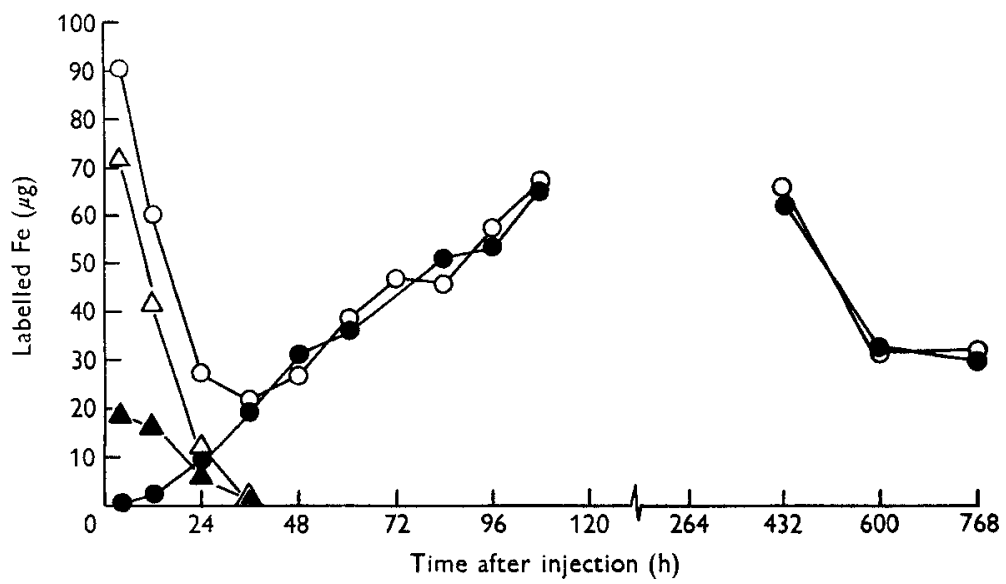

Fig. 7. Amount of labelled iron in, $\mathrm{-}-\mathrm{O}$, whole blood $(1 \mathrm{ml})$ of piglets and in, $\bullet-\bullet$, haemin, $\Delta \longrightarrow \Delta$, iron dextran, and, $\Delta-\Delta, \beta$-globulin contained in $\mathrm{I} \mathrm{ml}$ whole blood after an injection of $30 \mathrm{mg} \mathrm{Fe}$ as iron dextran.

the high activity of the blood up to $3^{6 \mathrm{~h}}$ can be attributed very largely to this component. The levels of labelled iron dextran and labelled $\beta$-globulin decreased throughout, until at $36 \mathrm{~h}$ after injection only very small amounts of both could be detected. The amounts of labelled $\mathrm{Fe}$ associated with $\beta$-globulin at 4 and $\mathrm{I} 2 \mathrm{~h}$ were considerably higher than the reported total iron-binding capacity of the plasma of about $5^{-\mathrm{ro}} \mu \mathrm{g} / \mathrm{g}$ (Ullrey et al. 1960; Campbell, 1961), and these high values may be a reflection of incomplete separation of iron dextran and globulins, which separation is particularly difficult at high iron-dextran concentrations.

Small amounts of labelled Fe could be detected in haemin isolated only $4 \mathrm{~h}$ after injection. This suggests that the compound is broken down to yield Fe which can be utilized for haemoglobin formation within a few hours of injection.

Except for piglets slaughtered at 48 and $84 \mathrm{~h}$, the labelled Fe of whole blood could be adequately represented by the sums of the contributions from haemin, iron dextran and $\beta$-globulin. No explanation of the two discrepancies can be offered. After $3^{6 \mathrm{~h}}$ very nearly all the labelled $\mathrm{Fe}$ in blood was in haemin, and as with the orally administered $\mathrm{Fe}$ there was no indication of a 'non-haemoglobin iron' fraction. 
Expt 4. The weight of labelled $\mathrm{Fe}$ in I $\mathrm{ml}$ whole blood from piglets which were injected with $\mathrm{I} 80 \mathrm{mg}$ labelled $\mathrm{Fe}$ and in the blood fractions isolated from it are shown in Fig. 8. Again, as only negligible activity was detected in $\alpha$-globulin and albumin fractions, values for them are omitted.

The mean values for the concentrations of labelled $\mathrm{Fe}$ detected in the dextran band obtained by electrophoresis and in the supernatant fraction obtained by precipitation were multiplied by the plasma volume to give the contribution of labelled iron dextran

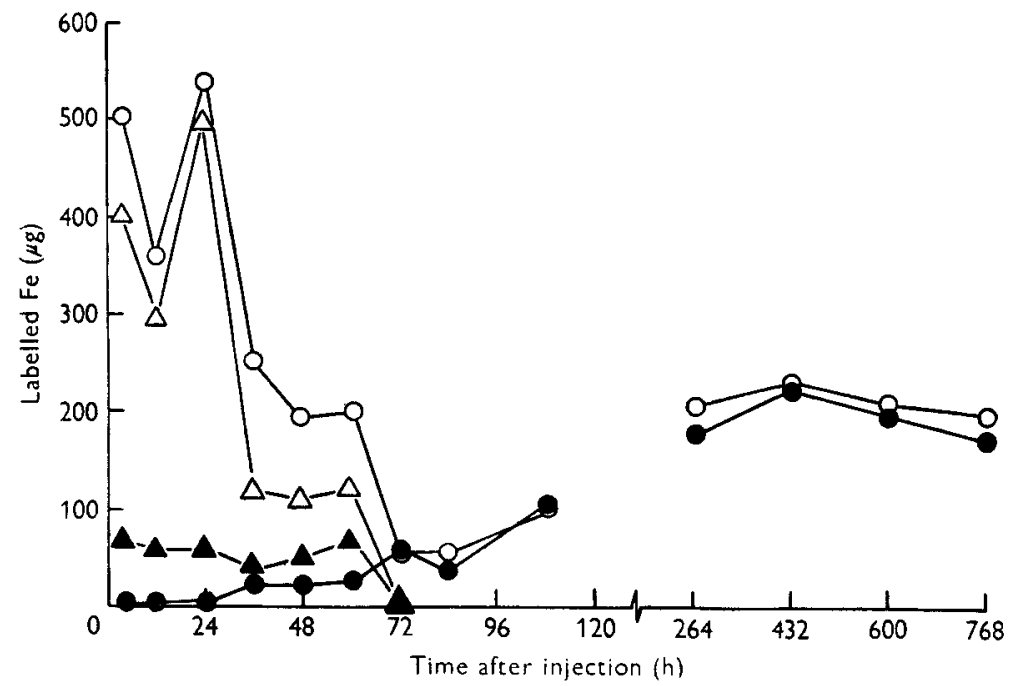

Fig. 8. Amount of labelled iron in, $\circ-0$, whole blood ( $1 \mathrm{ml}$ ) of piglets and in, $-\bullet$, haemin, $\Delta-\Delta$, iron dextran and, $\Delta-\Delta, \beta$-globulin contained in $1 \mathrm{ml}$ whole blood after an injection of $180 \mathrm{mg} \mathrm{Fe}$ as iron dextran.

to whole blood activity. As with the $30 \mathrm{mg}$ injection, agreement between the methods was good. It was so also with the values for the labelled $\mathrm{Fe}$ in $\beta$-globulin as prepared by electrophoresis and precipitation. Again the mean values are plotted.

The inadequacy of both methods of fractionation is clearly demonstrated, as the levels of labelled $\mathrm{Fe}$ in $\beta$-globulin in the plasma up to $72 \mathrm{~h}$ after injection were greatly in excess of the reported total Fe-binding capacity of serum. However, a dramatic fall in the levels of labelled iron dextran and labelled $\mathrm{Fe}$ in $\beta$-globulin occurred between 4 and $72 \mathrm{~h}$ after injection, that of the former falling from the typical very high level of $735 \mu \mathrm{g} / \mathrm{ml}$.

Once again small amounts of labelled Fe could be detected in the haemin isolated at $4 \mathrm{~h}$ after dosing, confirming that $\mathrm{Fe}$ from this source can be incorporated into haemoglobin by the piglet soon after administration.

The labelled Fe of whole blood could again be accounted for satisfactorily by the sums of the contributions from haemin, iron dextran and $\beta$-globulin.

Expt 5. In this experiment only negligible activity could be detected in the plasma, and in consequence the labelled Fe of whole blood was expected to be contained in the haemin. This supposition was confirmed, as shown in Figs. 7 and 8. For 
reasons stated on p. 429 , values for piglet no. 2 killed $264 \mathrm{~h}$ after injection have been omitted. With both doses, the fall in concentration at 600 and $768 \mathrm{~h}$ may largely be attributed to the diluting effect of the increase in blood volume of the piglets as they grew.

\section{Conclusions}

Results have shown that with piglets in their Ist week of life absorption of ferrous iron from a $30 \mathrm{mg}$ dose is unlikely to exceed $60 \%$. This percentage is of the order found by Ullrey et al. (r960), who recovered in the faeces $50 \%$ of an intake of about $30 \mathrm{mg} /$ day. Matrone et al. (i960) found that $30 \%$ of $\mathrm{Fe}$ in a diet containing $60 \mathrm{mg}$ $\mathrm{Fe} / \mathrm{kg}$ solids was utilized by piglets fed on fortified cow's milk and they were able to show that, once the small requirement of the tissues for $\mathrm{Fe}$ had been met, the remainder was incorporated into haemoglobin. Our results confirm this last finding, for we have observed that about $90 \%$ of the $\mathrm{Fe}$ absorbed, whether given by injection or orally, was incorporated by non-anaemic piglets directly into haemoglobin. Further, we were able to show that in these piglets the endogenous loss of Fe was extremely small. This leads to the conclusion that $90 \%$ of the requirement for Fe over the first weeks of life is represented by the requirement for haemoglobin synthesis. If a haemoglobin level of $8 \mathrm{~g} / 100 \mathrm{ml}$ blood and a blood volume of $70 \mathrm{ml} / \mathrm{kg}$ body-weight are assumed, then the requirement for $\mathrm{Fe}$ for haemoglobin synthesis is $\mathrm{I} 9 \mathrm{mg} / \mathrm{kg}$ liveweight increase and the total requirement about $2 \mathrm{I} \mathrm{mg} / \mathrm{kg}$ live-weight increase.

The fact that only about $79 \mathrm{mg}$ of Fe were absorbed from a total oral dose of $180 \mathrm{mg}$ when given over 6 days probably accounts for the fall in haemoglobin level at 3 weeks of age that has consistently been noticed at this Institute (Barber, Braude \& Mitchell I955). Probably insufficient Fe to cover the needs of the animals to an age when they begin eating creep food was supplied by this method of dosing. A possible improvement in the percentage absorption might be achieved by dosing on alternate days or at intervals of several days as up to $4^{8 \mathrm{~h}}$ after dosing there is too much $\mathrm{Fe}$ in the gut wall for efficient uptake.

When I $80 \mathrm{mg}$ Fe were injected as iron dextran, the mean amount recovered over the whole experimental period was $92 \cdot 7 \pm 4 \cdot 8 \%$. At $768 \mathrm{~h} 87 \%$ of the amount recovered was in haemoglobin, and a further $10 \%$ was in the tissues of the animal. Our findings suggest that this last quantity would be available for haemoglobin synthesis, so it would seem that $\mathrm{I} 80 \mathrm{mg} \mathrm{Fe}$ as iron dextran provides sufficient $\mathrm{Fe}$ to maintain a satisfactory haemoglobin level in the blood over the first 5 critical weeks of the piglet's life, before it begins to obtain Fe from creep food. It should be noted that over the first $4^{8 \mathrm{~h}}$ the rate of incorporation of labelled $\mathrm{Fe}$ into haemin from a $30 \mathrm{mg}$ oral dose was twice that from an injection of $30 \mathrm{mg} \mathrm{Fe}$ as the dextran (Figs. 4 and 7 ). Presumably this is because the factor limiting the rate of $\mathrm{Fe}$ incorporation from iron dextran is the rate of breakdown of this compound.

In order to ensure efficient utilization of the fraction absorbed from oral doses and the fraction removed from the site of injection of iron dextran, it is necessary to give sufficient $\mathrm{Fe}$ to maintain a haemoglobin level in excess of $6 \mathrm{~g} / 100 \mathrm{ml}$. If this is not done it seems that the processes of erythropoiesis are affected and that some of the $\mathrm{Fe}$ is not utilized for haemoglobin synthesis and is then excreted. 


\section{SUMMARY}

I. Five litters of 3 -day-old virus pneumonia-free Large White piglets were used to determine the retention and distribution by the young pig of labelled iron given either orally as ferrous sulphate or by injection as iron dextran. Either 30,90 or $180 \mathrm{mg}$ labelled Fe were given by oral administration, and either 30 or $\mathrm{I} 80 \mathrm{mg}$ by injection.

2. About $60 \%$ of a single oral dose of $30 \mathrm{mg}$ labelled Fe was 'retained' up to $240 \mathrm{~h}$ after dosing; thereafter up to $384 \mathrm{~h}$ there appeared to be an excretion of $\mathrm{Fe}$. About $53 \%$ of a daily dose of $30 \mathrm{mg}$ labelled Fe given on 3 successive days was 'retained' up to $240 \mathrm{~h}$, but when the same dose was given on 6 successive days only about $30 \%$ was 'retained'. No excretion of labelled Fe occurred between 240 and $384 \mathrm{~h}$ after dosing with six daily doses.

3. The amounts of labelled Fe recovered from different segments of the gut wall, liver, blood and gut contents after oral dosing are given. The importance of the liver in Fe storage and of different segments of the gut wall in Fe absorption is discussed.

4. About $99 \%$ of a single injection of $30 \mathrm{mg}$ labelled $\mathrm{Fe}$ was present in the tissues of the piglets up to $264 \mathrm{~h}$ after administration. Subsequently, up to $768 \mathrm{~h}$, results suggest that a marked excretion of labelled Fe occurred. No such excretion occurred after injection of $180 \mathrm{mg}$ labelled $\mathrm{Fe}$, the mean amount recovered over the whole experimental period being about $93 \%$.

5. The amounts of labelled Fe recovered after injection from different segments of the gut wall, liver, blood and the site of injection, together with the concentrations of labelled $\mathrm{Fe}$ in urine, bile, gut contents and some lymph glands are given. The importance of the liver in $\mathrm{Fe}$ storage is again shown and the rates at which $\mathrm{Fe}$ was removed from the site of injection, transported to the liver and other tissues and incorporated into haemoglobin are shown.

6. Fractionation of blood taken from animals that had received labelled $\mathrm{Fe}$ either orally or by injection showed that the Fe of whole blood could be adequately represented by the sum of the contributions from haemin and plasma at all times after administration.

7. It was estimated that a piglet must retain $21 \mathrm{mg} \mathrm{Fe} / \mathrm{kg}$ live-weight increase in order to maintain a satisfactory level of $\mathrm{Fe}$.

We are indebted to Dr R. F. Glascock who provided radioactivity counting facilities, to $\mathrm{Mr}$ S. H. Phillips for assistance in performing the assays, and to Benger Laboratories Ltd, Holmes Chapel, who prepared the radioactive iron dextran.

\section{REFERENCES}

Aleksandrowicz, J. (1955). Hematologia Kliniczna, p. 27. Warsaw: Panstwowe Zakłady Wydawnictw Lekarskich.

Barber, R. S., Braude, R. \& Mitchell, K. G. (1955). Vet. Rec. 67, 348.

Bauer, F. \& Becker, W. (1959). Tierärztl. Umsch. r4, 88.

Brown, E. B. \& Justus, B. W. (1958). Amer. F. Physiol. 194, 319.

Bush, J. A., Mahoney, J. P., Mankowitz, H., Gubler, C. J., Cartwright, G. E. \& Wintrobe, M. M. (1955). F. clin. Invest. 34, 1766. 
Campbell, E. A. (r96r). Aust. vet. F. 37, no. 3, p. 78.

Conrad, J. H., Plumlee, M. P. \& Beeson, W. H. (1958). Purdue Swine Day, Mimeo AS. 236.

Davidson, L. S. P., Fullerton, H. W., Howie, J. W., Croll, J. M., Orr, J. B. \& Godden, W. (r933). Brit. med. F. i, 685 .

Fischer, H. (194I). Org. Synth. 21, 83 .

Golberg, L. (1958). In Iron in Clinical Medicine, p. 74. [R. O. Wallerstein and S. R. Mettier, editors.] Berkeley, California: University of California Press.

Greenberg, A. \& Erickson, D. (1944). F. biol. Chem. 156, 679.

Greig, W. A. (1960). Vet. Rec. 72, I 149 .

Hahn, P. F., Ball, W. F., Ross, J. F., Balfour, W. M. \& Whipple, G. H. (1943). F. exp. Med. 78, 169.

Hansard, S. L., Sauberlich, H. E. \& Comar, C. L. (I95I). Proc. Soc. exp. Biol., N.Y., 78, 544.

Heilmeyer, L. (1958). In Iron in Clinical Medicine, p. 24. [R. O. Wallerstein and S. R. Mettier, editors.] Berkeley, California: University of California Press.

Jandl, J. H., Inman, J. K., Summons, R. L. \& Allen, D. W. (r959). F. clin. Invest. 38, r6r.

Jensen, W. N., Bush, J. A., Ashenbrucker, H., Cartwright, G. E. \& Wintrobe, M. M. (1956). F. exp. Med. ro3, 145 .

Josephs, H. W. (1954). F. Lab. clin. Med. 44, 63 .

Koechlin, B. A. (1952). F. Amer. chem. Soc. 74, 2649.

Kotarbińska, M. (I960a). Postępy Nauk rol. 22, 23.

Kotarbińska, M. (1960b). Roczn. Nauk rol. B, 76, 475.

McCance, R. A. \& Widdowson, E. M. (1937). Lancet, $233,680$.

McDonald, F. F., Dunlop, D. \& Bates, C. M. (1955). Brit. vet. F. IIx, 403.

Matrone, G., Thomason, E. L. Jr. \& Bunn, C. R. (I960). F. Nutr. 72, 459.

Moore, C. V. (196r). Harvey Lect. Ser. 55, pp. 67-ror.

Moore, C. V., Arrowsmith, W. R., Welch, J. \& Minnich, V. (1939). F. clin. Invest. 18, 553.

Moore, C. V. \& Dubach, R. (195I). Trans. Ass. Amer. Phycns, 64, 245.

Muir, A. R. \& Golberg, L. (196r). Quart. F. exp. Physiol. 46, 289.

Seamer, J. (1956). Vet. Rev. Annot. 2, 79.

Shemin, D., London, I. M. \& Rittenberg, D. (1950). F. biol. Chem. 183, 757.

Ullrey, D. E., Miller, E. R., Thompson, O. A., Ackermann, I. M., Schmidt, D. A., Hoeffer, J. A. \& Luecke, R. W. (1960). 7. Nutr. 70, I87.

Ullrey, D. E., Miller, E. R., West, D. R., Schmidt, D. A., Seerley, R. W., Hoeffer, J. A. \& Luecke, R. W. (1959). F. Anim. Sci. 16, 1038.

Venn, J. A. J., McCance, R. A. \& Widdowson, E. M. (1947). F. comp. Path. 57, 314.

Wright, E. (1957). N.Z. F. Sci. Tech. Sect. A, 38, rogr. 